\title{
Exploring Systemic Risk of Chinese SIFIs Using a Simplified SRISK Model
}

(Explorando o Risco Sistêmico de SIFIs Chineses usando um Modelo SRISK Simplificado)

\author{
Muhammad Jamal Haider * \\ Adrian Hemmes** \\ Gao Changchun *** \\ Tayyaba Akram ${ }^{\#}$
}

\begin{abstract}
The exposure of banks to systemic risk has been rising in an ever more financialized and interconnected economy. In China, economic slowdown and more non-performing loans mean that the financial system has operate in an increasingly stressed environment, strengthening the vulnerability of future systemic shortfall. In this study, systemic risk in Chinese systematically important financial institutions (SIFIs) is analyzed using a simplified SRISK model. The results are set into historical context, its characteristics are illustrated, and compared to an existing risk index. With that the study contributes to the existing literature by exploring application the SRISK model from a regulatory framework and illustrating some of its implications on Chinese SIFIs. The key findings include (1) an increasing trend of systemic risk exposure and (2) evidence for a divergence between volatility and systemic risk since the 2008 financial crisis.
\end{abstract}

Keywords: Systematic Risk, SRISK Model, Systematically Important Financial Institutions (SIFIs), China.

Submetido em 18 de março de 2017. Reformulado em 18 de março de 2018. Aceito em 18 de março de 2018. Publicado on-line em 18 de junho de 2018. O artigo foi avaliado segundo o processo de dup lo anonimato além de ser avaliado pelo editor. Editor responsável: Marcio Laurini.

* Glorious Sun School of Business and Management, Donghua University, Shanghai, China. E-mail: jamalhcc@hotmail.com

${ }^{* *}$ Centre of international program, Donghua University, Shanghai, China. E-mail: adrian.hemmes@gmail.com

*** Glorious Sun School of Business and Management, Donghua University, Shanghai, China. E-mail: gcc369@dhu.edu.cn

\# Glorious Sun School of Business and Management, Donghua University, Shanghai, China and FMS, BUITEMS, Quetta, Pakistan. E-mail: tayyabal.akram1@ @otmail.com

Rev. Bras. Finanças (Online), Rio de Janeiro, Vol. 15, No. 3, September 2017,pp.469-509 ISSN 1679-0731, ISSN online 1984-5146

(C)2017 Sociedade Brasileira de Finanças, under a Creative Commons Attribution 3.0 license $\mathrm{http}: / /$ creativecommons.org/licenses/by/3.0 
JEL Codes: F37, G15, G21.

\section{Resumo}

A exposição dos bancos ao risco sistêmico vem aumentando em uma economia crescentemente financeira e interconectada. Na China, a desaceleração econômica e mais empréstimos inadimplentes significam que o sistema financeiro opera em um ambiente cada vez mais estressado, fortalecendo a vulnerabilidade de um futuro déficit sistêmico. Neste estudo, o risco sistêmico em instituições financeiras sistematicamente importantes (SIFIs) chinesas é analisado usando um modelo SRISK simplificado. Os resultados são definidos no contexto histórico, suas características são ilustradas e comparadas a um índice de risco existente. Com is so, o estudo contribui para a literatura existente, explorando a aplicação do modelo SRISK a partir de uma estrutura regulatória e ilustrando algumas de suas implicações nas SIFIs chinesas. As principais conclusões incluem (1) uma tendência crescente de exposição ao risco sistêmico e (2) evidências de divergência entre volatilidade e risco sistêmico desde a crise financeira de 2008.

Palavras-Chave: Risco Sistemático, Modelo SRISK, Instituições Financeiras Sistemicamente Importantes (SIFIs), China.

\section{Introduction And Lite rature Review}

\subsection{Defining Systemic Risk}

After the financial crisis of 2008, systemic risk's popularity surged as academics raced to explain its inner workings, this transgressed the usual academic segregation and materialised in widespread interdisciplinary attention. Especially because some aspects of the banking industry make it more susceptible to systemic risk, and thus their failure a more problematic event for the whole economic system. According to Bullard et al. (2009), these are a high level of interconnectedness, high leverage ratios, which both are inherent to the nature of the financial industry, and a maturity mismatch at its core activity between its debit and credit transactions. It is this liquidity providing activity that presents bank's main valueadded function. And, similarly, it is the failure to provide this service to an economy that partly relies on it that can have the most adverse effects. In times of strong financial globalisation and increasing interconnectedness of banks, susceptibility to system failure $470 \quad$ Revista Brasileira de Finanças (Online), Rio de Janeiro, Vol. 15, N. 3, September 2017 
increases as well. Calluzzo and Dong (2015) confirmed the changing nature of the banking system. The authors conclude that while individually, banks were able to increase their financial soundness, collectively they gained vulnerability.

A comprehensive definition of systemic risk for financials can be found in Acharya, Engle, and Richardson (2012), who collected three main components and the product accurately reflects what systemic risk implies for a firm and its stakeholders. Those three components are the costs to society in terms of capital shortfall, the likelihood that the crisis event happens, and the capital shortfall a firm can expect should such an event happen. Building up on the works of Bernanke (1983), Slovin et al. (1993), Thakor (1996), Holmstrom and Tirole (1997), and empirical workings of Gibson (1995), the three authors identified two overarching ideas behind systemic risk: (1) if there is not sufficient capital, performing financial services is impossible and (2) that systemic risk only becomes important when it affects the whole economy. This study will use this definition, as it contains the key characteristics that are useful within the scope of this thesis, namely that in times of capital shortfall within the system financial services are inhibited, which in turn has a real effect on the overall, broader economy.

The single, individual elements of systemic risk are more difficult to narrow down, and no comprehensive definition has so far emerged (Bisias et al., 2012; Galati \& Moessner, 2010). The researchers find that the definitions usually portray only ever one specific aspect of systemic risk. Eijffinger's (2011) collection of systemic risk definitions finds that they all show at its core an impairment of the material workings of the financial industry, usually by a loss of confidence and increased uncertainty. Building on this, Smaga (2014) found four key elements that describe systemic risk. Firstly, systemic risk affects a large part of the financial system and impairs the working of this system. Secondly, shocks-usually exogenous - move along the interconnected system and negatively affect the overall economy. Thirdly, after the 2008 crisis, systemic risk has grown more popular. Lastly, the negative impact to the real economy is connected to the impairment of the financial functions 
that mostly happen only after the crisis. Comparing this to the definition of Acharya, Engle, and Richardson (2012), most elements are congruent and consistent with the findings of Smaga (2014). The key features of lacking liquidity and ability to performing financial services are, in fact, dominant features in most of the literature reviewed above. Acharya, Engle, and Richardson (2012) went beyond that and add an important distinction that serves both for practicality and ease of use, namely that systemic risk is only important when it threatens the wider economy. This does not mean that it should be ignored in times of economic upswing. In addition to that, it should be pointed out that systemic risk is not an excuse to provide banks with unlimited capital; these still need to fail for efficient markets to be able to function. The distinction adds, however, an important perspective that banking failure should be measured in terms of its real effect on the economy, as to avoid interfering with the efficiency incentive failures bring to the whole economic system.

When looking at systemic risk, it is often beneficial to focus at the biggest and most connected firms in the system, as these are most likely to have the biggest adverse impact on the system should it come to a crisis situation, for example, if these turn out to be undercapitalised and in need of a bailout. This study aims to analyse five Chinese financial services companies systemically important to the whole sector and indeed global markets. These SIFIs, as defined by the financial stability board (FSB), are institutions, which if failing would have significant effects on the broader economy. This definition is aligned with the two major characteristics of the definition of systemic risk employed in this study (1) the failure to perform financial services and (2) its impact on the wider economy.

\subsection{Systemic Risk in China}

The New York University's (NYU) Volatility Lab (V-LAB) features Chinese systemic risk indices prominently. This is no surprise considering that the Chinese economy grew from the last decade at an unmatched speed. Economic theory suggests that on each upswing follows a downturn, and it is in those downturns that banks who fall short of capital create a systemic risk threat to the 
whole economy. Now, China is a special case that requires a great deal of attention to detail, as many of the nuances do not align with those of the US or European markets.

Most of the research from China focuses on macroprudential measure and policy regulation implications of systemic risk, as well as the question of interconnectedness. Few studies look at tail losses and expected shortfall. The principle of marginal shortfall has been applied and found working in its bases. Fan, Wang, and Fang (2011) applied the MES and SES measure to Chinese institutions and empirically verify that in crisis situations higher MES correlates with higher SES. Gao and Pan (2012) looked at the risk of contagion for Chinese banks in the year of 2009. The authors' scrutinised possible ways systemic risk could spread and look at implications for liquidity and creditworthiness. The researchers find contagion within a concentrated version of their sample, especially for BOC and ICBC. They further find that the capital adequacy ratio and risk exposure are two important factors determining how a bank is affected in a crisis situation. Also focussing on contagion, Li and Meng (2012) illustrated that reserve requirements are by far the most powerful tools preventing contagion. The authors suggested that other risk control tools should follow suit. Similarly, Ma, Fan, and Cao (2007) looked at balance sheet information and interconnectedness as a gauge for systemic risk.

One aspect specific to systemic risk in China is the predominant shadow banking sector. $\mathrm{Hsu}, \mathrm{Li}$, and Xue (2014) found that during China's shift toward a modern banking system many informal lending practises were left unapprised for risk. Indirectly linked by credit guarantors, banks may face unforeseen losses connected to the informal industry. Exacerbated is this by the perception that the government guarantees deposits of the formal banks. The authors found that, for example, trust companies contributed greatly to systemic risk because of their high level of liabilities and interconnectedness with other institutions.

Bekaert and Harvey (1997) suggested another indication at how emerging financial markets behave differently from more 
developed capital markets. Amongst other findings, the authors confirmed empirically that with capital market liberalisation, volatility in those markets decreases. The authors further suggested that world events have a bigger say in developed capital markets, while local events play a more important role in more closed markets. While seemingly obvious, this implies an important mean of caution when analysing China's capital markets for systemic risk. For that, one should take into account the stages of development of the country's capital market during the timeframe considered in the analysis.

\subsection{SRISK and Other Models}

Early approaches to systemic risk were made by Acharya (2001), who laid out the theoretical framework for a systemic risk way of looking at banking regulation, long before the defining crisis of the $21^{\text {st }}$ century hit. He discovered that banks usually act together when the negative effects of the potential crisis outweigh the potential gains that can be made from a potential reduction in competition due to failures during the crisis. In his findings, the author suggested that banks should be incentivised to diversify by means of taxation and conditional bailouts by central banks. In subsequent researches, the author together with other authors from NYU Stern's Volatility Lab, analyse the implications and viability of volatility measures, which should eventually create the SRISK analysis as means of capturing the amount of capital a firm will lack conditioned on an overall market downturn.

SRISK aims to internalise some externalities of systemic risk and provide the grounds for macro-prudential regulation that make bank failures obsolete as at any time the institutions within the system hold enough capital to avoid contagion and step in to provide the services the failing bank falls short of (Acharya, 2001). Such preemptive means of regulation have the obvious advantage that the probability of a real capital shortfall is greatly reduced, but many of the implications this will have on banks risk taking behaviour are not yet known. 
Building on this framework, Acharya,Engle, and Richardson (2011) discussed some advantages of the SRISK measure. The authors found that it gives similar results as conventional stress test do, but can be created with publicly available data. This has important implications for transparency. While before researchers and analysts had to rely on official, mostly internal data, they now can gauge risk exposure using the market-based model. The same authors, Acharya, Engle, and Richardson (2012) and Brownlees and Engle (2016) first comprehensively used the SRISK approach to simulate capital shortfall in a crisis situation. The statistical tool shows how equity fails to provide enough capital to support the bank's leverage under stress. At the same time, it assumes that beyond government institutions firms are unlikely to buy the banks with shortfalls out, as those are also struggling with lack of capital themselves. The output is a monetary estimation of the value lost to the system.

Engle, Jondeau, and Rockinger (2014) extended the SRISK analysis to 196 European banks. Combining data over 12 years, the authors found that for some banks the cost of rescuing would be unsustainable and too big a dent in the public finances of the European Union. They asserted that applying the measure to institutions outside the United States comes with various difficulties. These include a multitude of origins of potential crises, especially when analysing banks in the fragmented European making landscape. Furthermore, two other challenges that the present study accounted for are time-sensitive betas and potential time difference to the market in which the crisis is most likely to originate, in their case the United States. For regionally originated crises, time sensitive beta and potential time differences need not be adjusted for the authors conclude.

Beyond that, the SRISK model has beenfrequently compared and assessed in its predictability by various researchers. For example, Acharya, Pierret, and Steffen (2016) looked at a comprehensive sample of European banks and compared three different methods of estimating capital shortfall. These three methods included a replication of a recent European Banking Association (EBA) stress test, a Comprehensive Capital Analysis and Review (CCAR) 
approach mainly used by the Federal Reserve Bank in the US, and SRISK. Their findings stated that the two-book value-based stress tests show significantly less capital shortfall compared to the SRISK measure, this is mainly attributed to the difference in prudential capital requirements used in the calculations and the difference between market value of equity used in SRISK and book value of equity, as well as bigger losses under the stress scenario the banks were subjected to. The lowest capital shortfall prediction was made using the EBA approach, followed by the CCAR, with SRISK predicting the highest capital shortfall with a significant gap between the two other measures. The researchers pointed out that this is an important difference policy makers should include in their decisionmaking.

In their work, Giglio, Kelly, and Pruitt (2016) mentioned some of the limitations of the model include the fact that a marketbased pricing of equity might become problematic as it includes market perceptions of the future. This is taken by some as an advantage and others as a disadvantage. Further problems, which have to be taken into consideration when applying the SRISK measure, are that the capital requirements might differ for different asset classes, limitations to balance sheet figures, and the shortcomings with simulating the shortfall as prolonged event. However, the author finds that the SRISK measure beats the VIX volatility index in the longer run in its ability to predict systemic risk. Hansen (2013) identified some general issues with researching and especially measuring systemic risk. The author stressed the need to follow a scientific approach, looking at a formalised question and supporting it with data. It is further warned against stopping short of the scientific approach but at the same time the necessity of what the author calls "short-term" research is acknowledged, as long as it is not used as basis for policy decision (Hansen, 2013).

Even though the SRISK model works well in its theoretical framework, it is still in the process of being ratified by academic literature. Recent additions, such as Engle's (2012a) dynamic conditional beta (DCB) estimation are responses to those ratifications and suggestions for improvements. The potential for this model to 
create strong quantitative and qualitative policy advice is immense, and should the ratification process come to fruition, so could SRISK soon be easily priced into financial transactions or could be accounted for with stricter minimum capital requirements, as suggested by Acharya, Engle, and Richardson (2012).

\section{Methodology}

The present study applied a simplified form of the SRISK measure as means to illustrate the relationship of systemic risk and leverage historically for Chinese financial institutions, more specifically Chinese SIFIs. The aim of this study was to underline the ability to easily replicate the model, as well as a qualitative and quantitative evaluation of some of the implications of its simplified form, with a core focus on its ability to capture the performance tradeoff.

\subsection{Unit Of Analysis}

Contrary to macro stress tests, this study was conducted on organisational level, from which a state of the whole economy can be extrapolated. All data has been taken from publicly available sources, namely yahoo finance and the financial institution's annual statements.

\subsection{Sample Size}

Altogether, seven Chinese financial institutions were the focus of this study's analysis. Data was collected from immediately before the financial crisis of 2008, amounting to-where data was available10 years of historical data. Five of the firms analysed are categorised as systemically important by the FSB. These include China's four globally systemically important banks (G-SIBs) Industrial and Commercial Bank of China (ICBC), Bank of China (BOC), China Construction Bank (CCB), and Agricultural Bank of China (ABC), as well as the country's only globally systemically important insurer (G-SIIs) Ping An Insurance (PA). The categorisation is published periodically, and the named institutions represent China in the most recent report of 2015. When taking data from the latest annual statement of the People's Bank of China (PBC), the influence of these G-SIBs amounts to roughly $38 \%$ of the total assets in the market. 
Special focus was given to the two former most institutions, ICBC and BOC, as they were used as an example to illustrate implications between SRISK and some traditional performance measures. In addition to that, two more institutions were included China Life Insurance and Evergrande. The former as a counter example because it constantly features as one of the lowest SRISK exposed institutions in the V-Labranking, the latter, as an illustration of SRISK behaviour in China's real estate market.

\subsection{Type Of Study}

The study quantitatively constructed the simplified SRISK measure following it over a time-period of ten years. The dataset was then set into historical contexts and individual characteristics were evaluated by illustration. One of these was a different market scenario to simulate the downturn. In a similar way, evidence for the measure's implications on future returns are explored and in concurrence with other findings dismissed. Lastly, the model's congruence with volatility is explored as well.

\subsection{Analysis Tools And Techniques}

All numerical exercises were conducted using MS Excel and correlation analysis was done using SPSS. Figures and tables also were generated from the two programs. The theoretical tools applied are anchored at two concepts, firstly, a general stress test framework and secondly, the model applied in the reduced form. The following sections discuss these theoretical tools.

Before moving on to a detailed explanation of the assumptions and components of the SRISK model and how it was employed, the present study spent significant time setting up the general approach of the model into the context of conventional stress testing. This helped to understand the goals of the numerical exercise, as well as some of its limitations. The SRISK model, then, fell into the category of reverse stress testing. This means that instead of calculating default probabilities, the measure assumes a stressed economic environment and models the response of the institution in question. Both approaches aim to find the point at which the institution cannot meet its obligations anymore and enters technical 
insolvency. Reverse stress tests specifically have the advantage of working with certainties and gauging the resilience of a system and institution under stress scenarios. In its scope, SRISK falls into the category of a satellite model. Contrary to macroeconomic models, it considers individual banks and aims to aggregate these for a systemwide view of systemic risk.

\subsection{Assumptions}

Essential to the working of this model, and its scope of application, are its assumptions. The methodology applied is based on few key assumptions. First, it has to be noted that the model created within the scope of this study will be a simplified form model intended to illustrate key relationships between SRISK and other measures. This means that the results are more indicative rather than aiming to give a very accurate measure. To achieve the latter, this study suggests employing stronger estimations to determine the variables of the model, which transgresses the scope of this study.

Furthermore, the model assumes considerably efficient markets and follows the efficient market hypothesis (Fama, 1998). Important to the model's ability to predict is the effective pricing power of the market. A miss-pricing of assets has before led to a global crisis; today markets are getting more and more illiquid which may again cast doubt on the effective pricing argument. Counter to this perspective goes the argument that after the crisis, investors and other market participants started considering risk more strongly in their evaluation of assets. Amihud, Mendelson, and Pedersen (2006) recommended that the model's assumption generally hold in today's environment in spite of decreased market liquidity, however, in terms of CAPM beta, the authors suggest adjusting it for liquidity. Moreover, they also argued that it is important to consider the relative pricing power of efficient markets, whose efficient price may be affected by various factors. In generally, the more model's effectiveness increases, the more accurate the market prices will be.

Another key assumption is that the beta is sensitive to the future prices of an asset. Depending on the estimation used, this is a varyingly accurate assumption. Academic literature (Fama and 
French, 1992 amongst others) suggests that the simply regressed CAPM beta used in this study has limited predictability. It, however, does capture basic trends, which were considered sufficient for the scope of this study. More effective is the DCB beta according to Bali, Engle, and Tang (2012), who find that betas estimated with the autoregressive model have significant implications on future prices.

Bank stress testing can follow different frameworks, and as explored earlier tries to quantify consequences a bank faces when it is set under economic stress, for example, a recession. The IMF (2014) suggests six steps framework for stress testing, following Jones, Hilbers, and Slack (2004). First, areas likely to be affected or other vulnerabilities are singled out. Within the SRISK method, this is set as systemic risk. Second, the shock scenario is specified; here a market downturn of $40 \%$ over a course of six months. Note, however, that the SRISK model allows adjusting these measures. Third, key inputs from balance sheets and in this case market data are identified. Next, the analysis itself is conducted and, in a next step, any further effects that could impact the system singled out and considered. Sixth and last, the findings are summarised and analysed.

\section{Results And Discussions}

\subsection{Time Series Simulation Of A Downturn In The Hksi}

A downturn in the HKSI was modelled. As outlined in the methodology, SRISK depicted here shows the difference between the current leverage ratio and one accounting for the impact of the crisis in terms of a capital shortfall. Below is a Figure of sevenkey financial institutions in China and their historical SRISK level over 10 years where data available. Each colour represents one institution and its relative systemic risk depicted as excess leverage over the recommended leverage accounting for a $40 \%$ downturn in the market.

The $\mathrm{X}$-axis is the line of maximal leverage at which the model suggests that there is no systemic risk and capital shortfall. There are few notes to the individual banks in FIGURE 1. Firstly, the four G-SIBs, ICBC (dark blue), BOC (red), AGC (green), and CCB (purple) have naturally the highest systemic risk exposures as they 
are closely linked with and within the financial system, and because the nature of their business requires them to hold comparably high leverage. While this is still lower than, for example, investment banks, it is yet higher than insurers (PING AN \& CHINA LIFE) and real estate companies (EVERG). One anomaly is PING AN (orange), which is pursuing an aggressive growth strategy growth strategy and engages in various return seeking activities, and as a counter example this study included CHINA LIFE Insurance (brown), which has consistently low systemic risk exposure. PING AN deemed to later fix this issues by doing a share split that quickly doubled its equity base. The re-pricing by markets did not materialise as starkly from a systemic risk point of view and the bank managed to significantly lower its leverage. This could potentially mean that the systemic risk measure can be manipulated by issuing excessive shares in low share price environments. Similarly, the model itself is also sensitive to excessive share issuing, which might cause distortion during the estimation of the beta. The Figure fits well in the historical and academic narrative, which will be explored further later. 


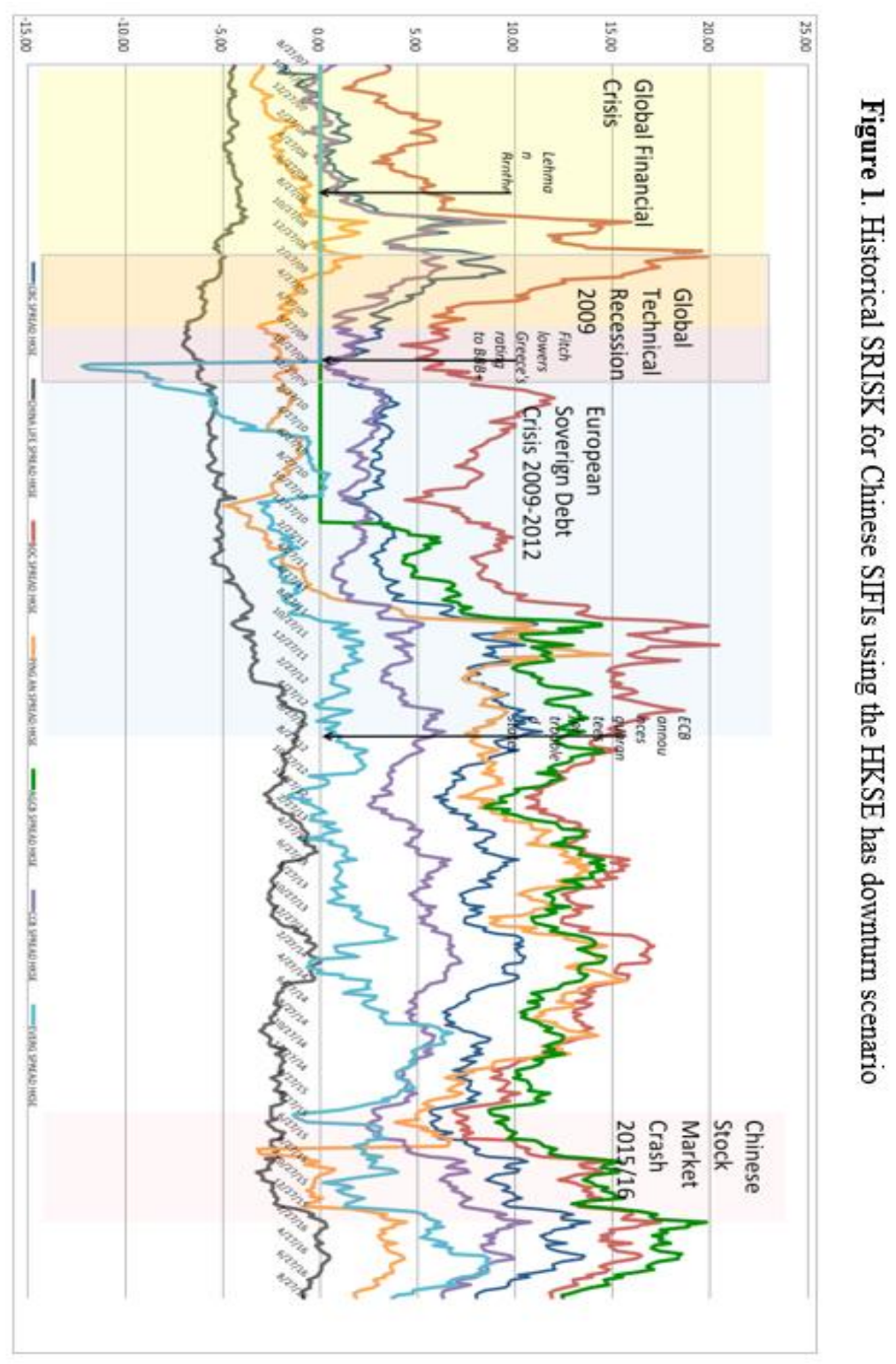


There are two major spikes in the table in 2008 and 2011, as well as a sustained period of higher risk in the period following 2011. The first important point is the 2008 financial crisis. After a prolonged episode in which most banks had low or even no systemic risk exposure, the financial crisis spread across the world and into Asia. After a period of higher and higher risk taking, mainly due to the miss pricing of the risk of assets (Basurto, Jones, Lindner, and Blankenheim, 2013; Shin, 2009), the turning point eventually came when Lehman Brothers filed for Chapter 11 in August 2008. This turned the crisis from a local, mainly US based credit shortfall into one that affected the whole world. Globally, markets fell sharply and this stress increased risk, and so did systemic risk. In Figure 1 this is represented by a big spike. The whole year of 2008 is dominated by the crisis, and only at the turn of the year systemic risk is decreasing. China's economy has suffered from spill over effects from this crisis but managed to mostly retain its growth trajectory. Yet, the economy was hit to a similar extend as most developed countries did, find $\mathrm{Li}$, Willett, and Zhang (2012), but most of this could be negated by strong fiscal discipline, big foreign exchange reserves, and limitations on capital movements. What is apparent, however, is that the Chinese market, due to its internationalisation, now, was heavily interconnected with global markets. This trend all but discontinued in the years that followed.

Paradoxically, SRISK is falling quite sharply for all firms during 2009, a year in which the world entered a technical recession. Shortly after the financial crisis was starting to subside, without delay, world markets were already affected by the next crisis looming.

The second period in which SRISK drastically spikes is mid2011 during the European sovereign debt crisis. There, a still lingering recession, higher risk lending, easy access to global and specifically European finance, and a housing bubble were among the culprits that should eventually leave the financial sectors of Greece, Portugal, Spain, Cyprus, and Ireland in need of a bailout. The core of the problem remained a structural problem with the Eurozone's monetary integration asserts Obstfeld (2013). The near default of 
multiple countries made stock markets tremble as it was feared the shortfalls could - similar to as it happened during the 2008 financial crisis - spread over a global scale. Eventually, the markets calmed on the promise of the European Central Bank (ECB) to guarantee the debt of troubled EU states in August 2012. Systemic risk played a major role in this crisis and its market downturn whiplash. The SRISK Figure picks up during August and September 2011 to reach its peak since the 2008 crisis.

Figure 2 shows the normalised adjusted market close of the HKSE, BOC's normalised adjusted stock price and its SRISK spread during 2011, the year in which global markets worried about contagion of the EU crisis. Besides the obvious negative correlation between the stock and the SRISK spread, which will be discussed shortly, the comparison of the normalised Figures illustrates well how SRISK works as a market-based measure. The first signs of worry in the market can already be seen in the beginning of the year, it takes, however, until June for it to begin to accelerate. A more muted, but similar effect can be seen in the HKSE and real value SRISK. The asset's effect as pricing tool becomes well apparent in Figure 2. As only majorly varying input to the model, its impact is in normalised from even more apparent. The two trend lines show that over shorter periods of time the asset pricing dominates the determination of SRISK. The two trend lines are drawn in the Figure further show that price movements in the asset are more sensitive than the SRISK measure.

While markets calmed and gained strongly, systemic risk remained present. In fact, while over the short term the institution's asset dominates pricing behaviour (Figure 2), over the long term SRISK seems to be more dominant in its trend outpacing the underlying asset. 


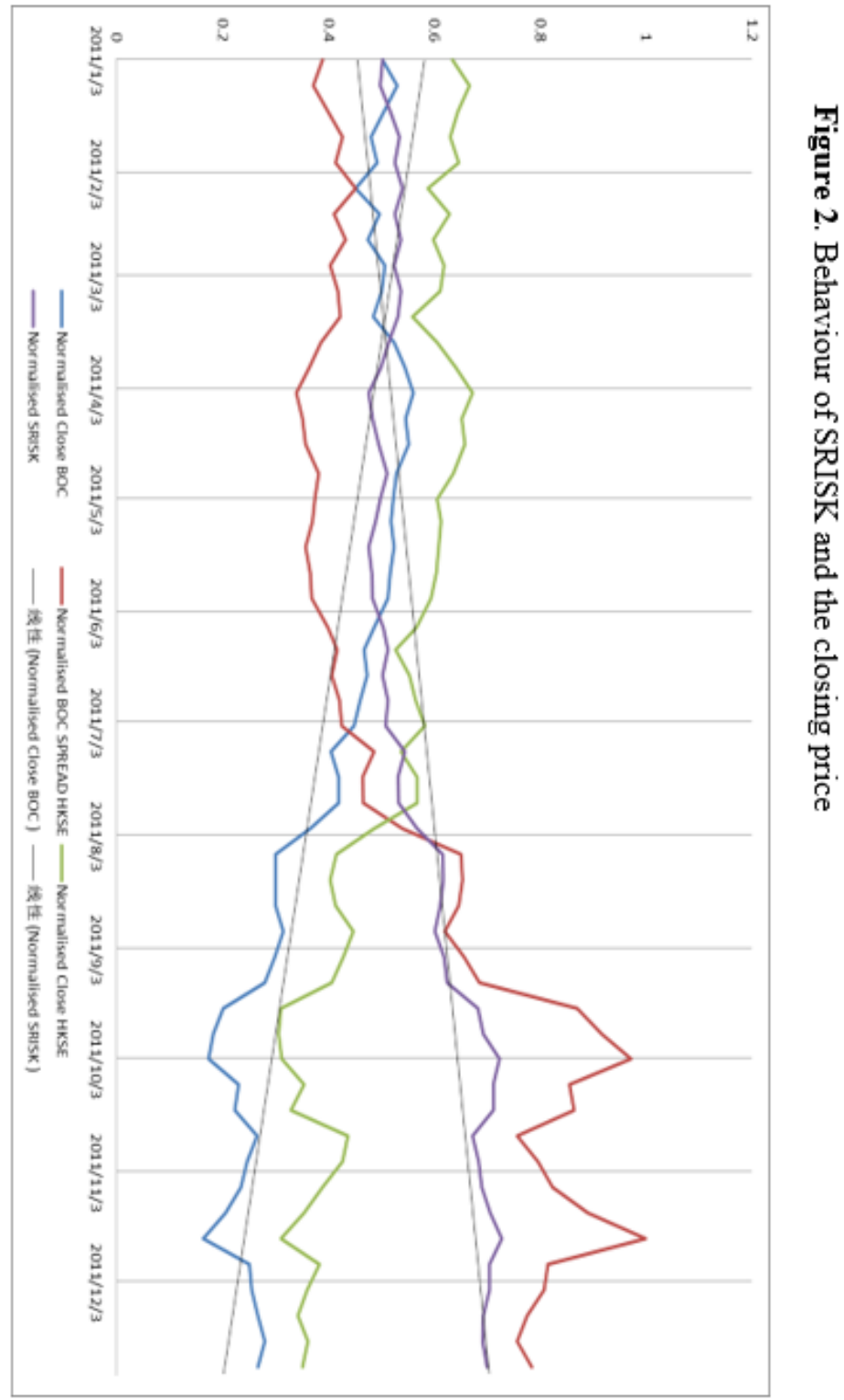


Figure 3 depicts the same lines as in Figure 2, but over a longer period of time. Here, the trend lines show a steeper increase in SRISK over the institution's asset. The heightened period of increased systemic risk exposure after the EU crisis explains much of this trend. Carried by balance sheet expansion that came with increased leverage, SRISK did not swing down with the market regain. Instead, the hits of the last crisis, which already had depleted banks equity buffers, remained in the system. The failure to reduce banking leverage is partly connected to the slowdown in China's economy and the increasingly debt-fuelled effort to keep the economy up. From 2010 to 2016 real year-on-year growth declined by a total of four percentage points. By no means trivial, this decline has serious implications on the structure and performance of bank lending, and almost all financial activity.

After a prolonged period of marginally increasing systemic risk, risk levels spiked again significantly during the summer 2015 and January 2016 Chinese stock market crashes. During this period, SRISK levels rose from their already elevated levels (Figure 1) to new heights.

Even though the risk event simulated was a downturn in the HKSE, and thus a more localised downturn, it is apparent that most major, global financial downturns have contagious effects on global markets; to a lesser extent but still significant. This happens mainly due to a more global trend that causes the financialization and globalisation of markets (Marois, 2012; Orhangazi, 2008; Gomez \& Korine 2008). Markets moving more and more in tandem, gives rise to increasing systemic risk exposure. This is accurately reflected by the model's market price component and can even be captured using simple estimations. Similarly, the short-term movements in SRISK respond to significant events giving rise to systemic risk, fail, however, to anticipate them. On the overall trend, this study finds that years of financial integration, globalisation, global crises, and local, economic slowdown left its mark on the exposure of Chinese financial institutions to systemic risk. International efforts, such as the BASEL Accords or Dodd-Frank Act, as well as domestic efforts to prop-up healthiness of the banks did not have the intended effects. 
Instead, market returns grew often at the expense of stability. The unfavourable macro environment adds to the foes. High level of SRISK exposure and leverage paint a troubled picture for the road ahead. In fact, any event causing sudden major stress to the system could trigger a new crisis, for example, a gone-wrong vote and sudden default of a bank are both possible scenarios for such an event. 


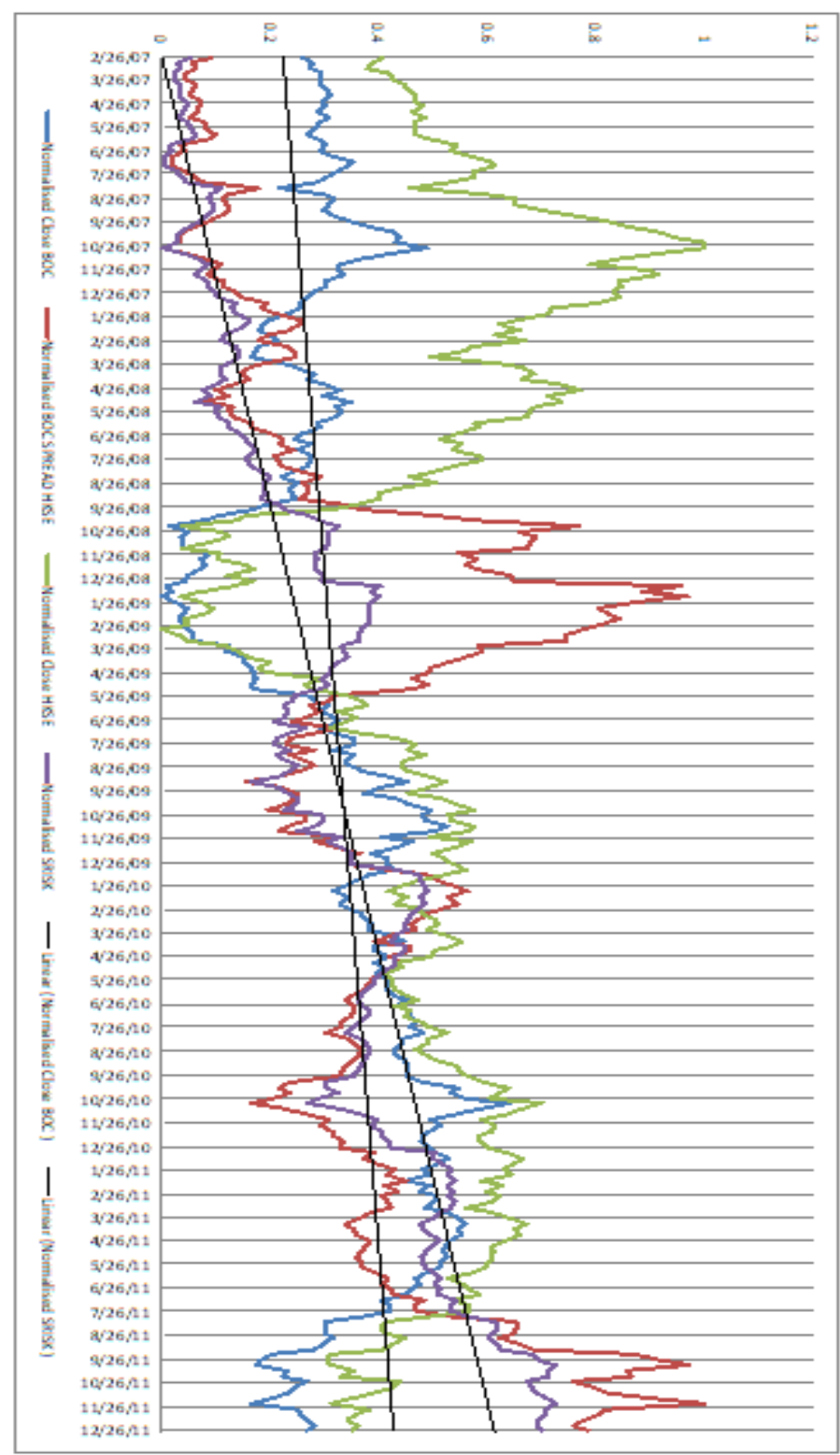

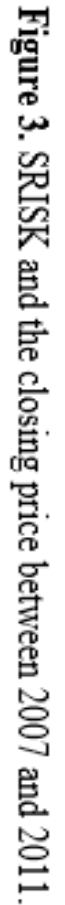




\subsection{Diffe rent Market Scenarios}

The model can look into various scenarios, for example, using the MSCI World Index as benchmark makes a global downturn cause of the systemic event. Is a local benchmark, such as the $S \& P 500$ or in the two scenarios of this study the MSCI Asia and HKSE, then the capital shortfall is based on a more localised downturn. From the illustration of SRISK based on a HKSE downturn above key features were identified that remerge in simulations based on other markets as well. For that, the sum of all systemic risk spreads of the sample institutions was taken for both, the HKSE and the MSCI Asia, and plotted in Figure 4. Starting at mind-2008 when the MSCI Asia was launched, the Figure shows that the MSCI Asia shows a more muted, but also more volatile SRISK.

The general upward trend can be observed foremost, in both cases, is visualised by a trend line. The three major events, 2008 crisis, 2011 EU sovereign debt crisis, and the 2015-16 stock market crashes are all strongly represented, in fact, the correlation coefficient between the two Figures is at 0.91 . 


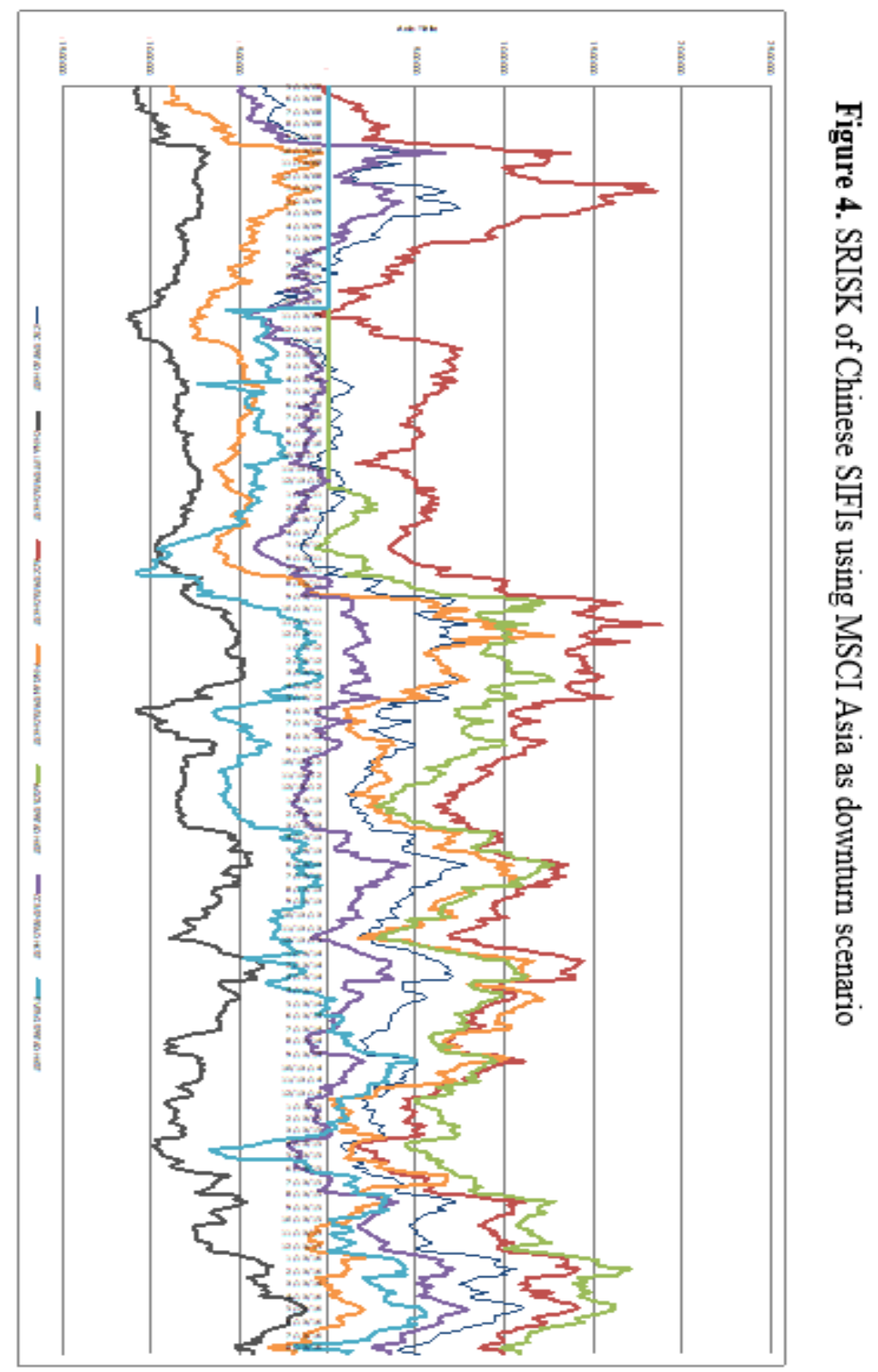


The general upward trend can be observed foremost, in both cases, is visualised by a trend line. The three major events, 2008 crisis, 2011 EU sovereign debt crisis, and the 2015-16 stock market crashes are all strongly represented, in fact, the correlation coefficient between the two Figures is at 0.91 .

\subsection{Simplified Srisk: A Forward-Looking Measure?}

When comparing the model's response to same period returns and ability to predict next period returns, this study found more evidence that the relatively simple mean employed to estimate the beta input is the models strongest limitation. While responsive to current period returns the measure lacks significant correlation to future time returns. This is not surprising as there is yet a model to emerge which can accurately predict future returns. Figure 5 and 6 depict the change in SRISK compared to the market returns at $t$ and $\mathrm{t}+1$ respectively. Immediately apparent is the linear relationship between simplified SRISK and the market returns of this period.

Figure 5. Scatter plot of $t$ returns and SRISK

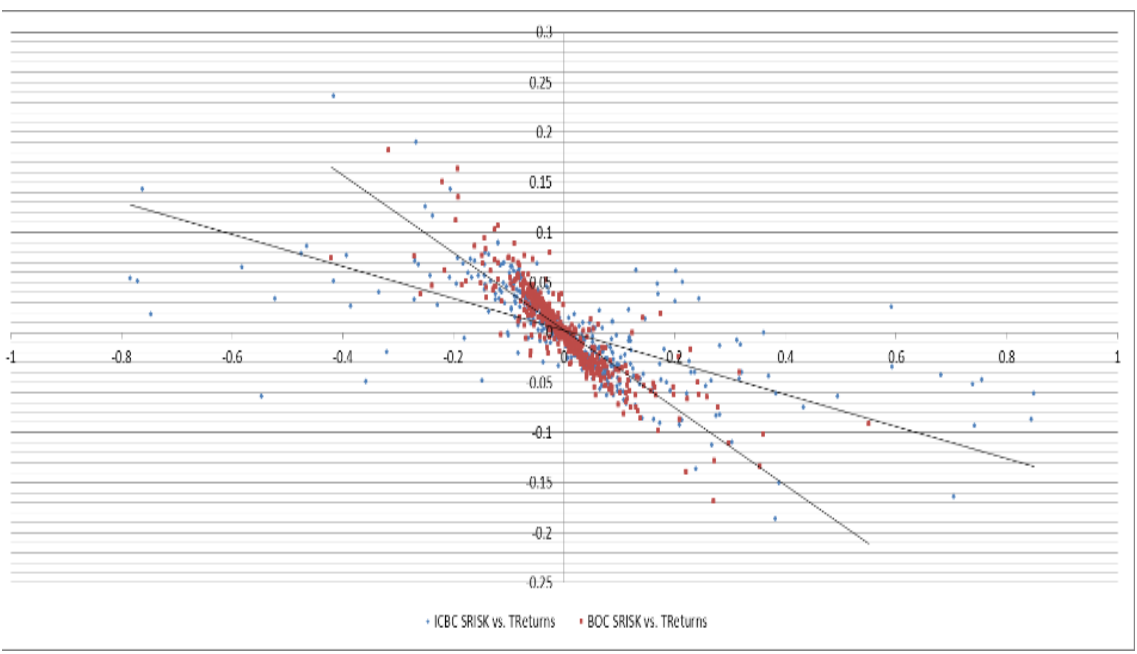


Table 1 (a). Correlation of ICBC SRISK with returns at $t$ and $t+1$

\begin{tabular}{lllll}
\hline & & CHANGEICBC & LOGRETURNICBC & RETURNT1ICBC \\
\hline CHANGEICBC & $\begin{array}{l}\text { Pearson } \\
\text { Correlation }\end{array}$ & 1 & $-.651^{* *}$ & -.043 \\
& Sig. (2-tailed) & & .000 & .348 \\
& $\mathrm{~N}$ & 470 & 470 & 469 \\
\hline
\end{tabular}

**. Correlation is significant at the 0.01 level (2-tailed).

(b). Correlation of BOC SRISK with returns at $t$ and $t+1$

\begin{tabular}{|c|c|c|c|c|}
\hline & & CHANGEBOC & LOGRET URNBOC & $\begin{array}{l}\text { RETURNT1BO } \\
\text { C }\end{array}$ \\
\hline \multirow[t]{3}{*}{$\begin{array}{l}\text { CHANGE } \\
\text { BOC }\end{array}$} & $\begin{array}{l}\text { Pearson } \\
\text { Correlation }\end{array}$ & 1 & $-.856^{* *}$ & .011 \\
\hline & Sig. (2-tailed) & & .000 & .816 \\
\hline & $\mathrm{N}$ & 470 & 470 & 469 \\
\hline
\end{tabular}

**. Correlation is significant at the 0.01 level (2-tailed).

Figure 6. Scatter plot of $t+1$ returns and SRISK

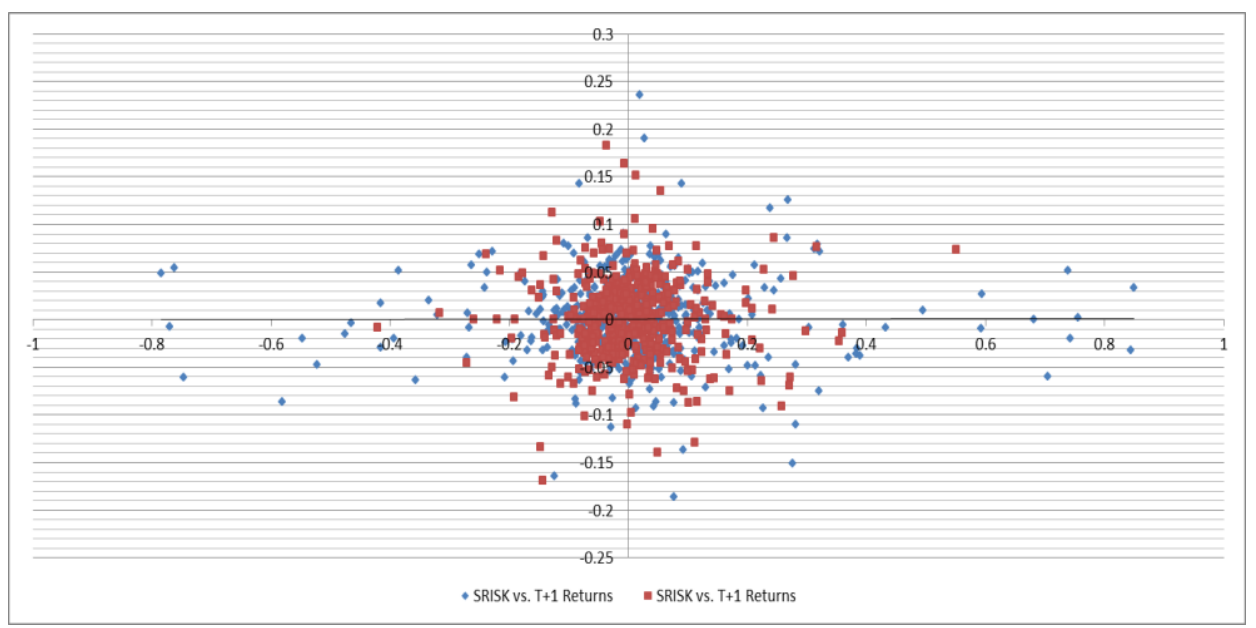


As the literature suggests, the linearity of the CAPM beta makes it difficult to derive accurate readings from it. In fact, this study found this to be one major weakness with the extremely simplified model. In cases where the index from which market value of liabilities are taken is identical with the one taken as basis for the downturn simulation, the SRISK and the representation used in this study show a strong negative correlation with the stock price. As the CAPM is based on past days prices, it implies that the SRISK measure constructed this way has limited indicative ability for future time horizons.

When exploring this linearity further (Figure 7) the study found a periodical shift outward. The Figure depicts SRISK and returns over 10 years for ICBC, the findings were confirmed when looking at all the other institutions sampled in this study. It is assumed that the drift in this linear relationship is due to balance sheet expansion but no findings confirming this relationship were found or attempted. Interestingly, this shift in linear relationships implies an increase of both SRISK and returns over a longer time frame. It is assumed that investors' expectations on risk are anchored in the short term, and that systemic events and crises, upend these expectations. Indeed, the Figure suggests that the biggest jumps in risk are happing directly after the crisis periods. 
Figure 7. Normalised SRISK and closing price, dated

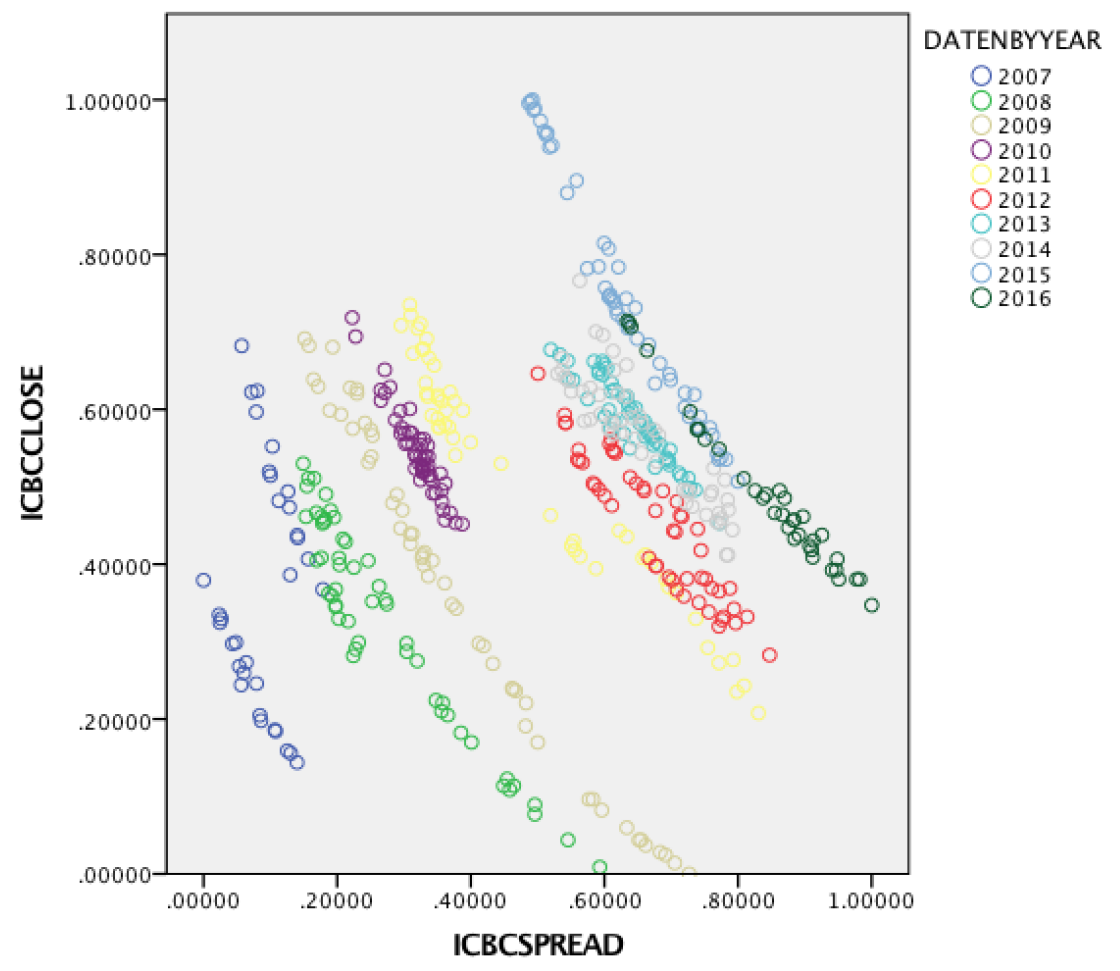

\section{Congruence With Volatility}

Similar to Brownlees and Engle (2016), the present study compared the resulting curve to an established volatility index, here the HKSE Volatility Index (VIX HKSE). Figure 8 shows the normalised SRISK compared to the normalised close of the VIX $H K S E$. SRISK here is the average SRISK for the week for all institutions of this study. Overall, the measures move in line together over the short term. The key events 2008, 2011, and 2015-16 are both represented in both Figures. Another obvious observation is, however, the diverging drift of the two risk measures. Long-term correlation confirms this trend with an overall negative correlation of -0.285. After almost unified movement during the 2008 crisis, the 
values split at the Euro crisis, a crisis deeply defined by systemic risk. After that, the SRISK measure is considerably higher than the VIX $H K S E$ measured at normalised range over whole observation period.

Table 2. Correlation between SRISK and HKSE Volatility index

\begin{tabular}{llll}
\hline & & AVGCLOSE & AVGSRISK \\
\hline AVGCLOSE & Pearson Correlation & 1 & $-.285^{* *}$ \\
& Sig. (2-tailed) & & .000 \\
& $\mathrm{~N}$ & 498 & 498 \\
AVGSRISK & Pearson Correlation & $-.285^{* *}$ & 1 \\
& Sig. (2-tailed) & .000 & \\
& $\mathrm{~N}$ & 498 & 498 \\
\hline
\end{tabular}

**. Correlation is significant at the 0.01 level (2-tailed). 


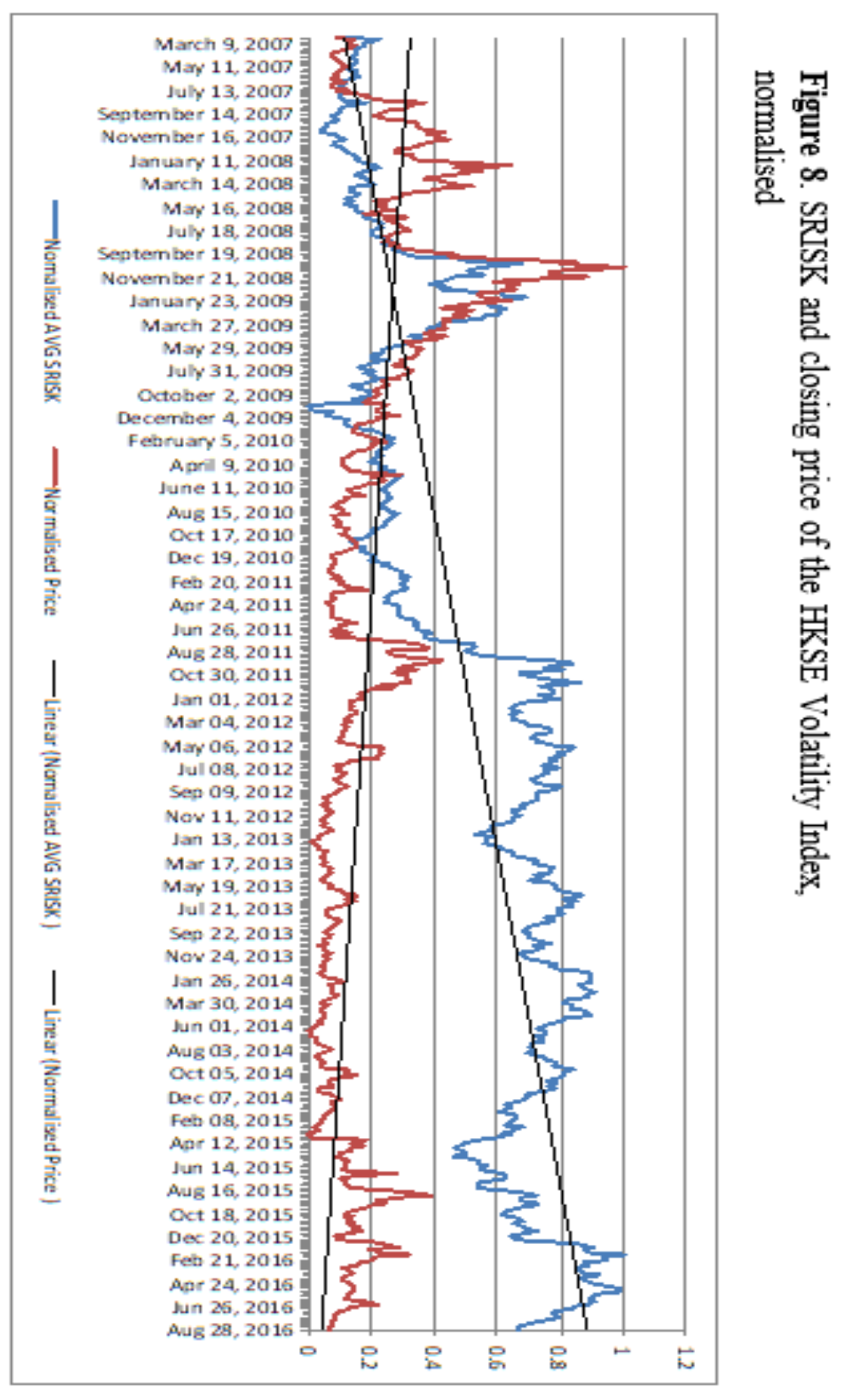




\section{Conclusion}

The present study concludes that indeed the simplified version of SRISK captures systemic risk exposure for Chinese systemically important institutions, and beyond. The representation chosen, in this study, allows gauging systemic risk from a more comparable, regulatory point of view. Indeed, relative ease of use and low data requirements suggest that this can be done from an independent researcher's perspective.

Empirical evidence of this study further hints at an increasing trend for systemic risk exposure that is not captured by most of the current prudential regulation. Set into the context of a slowing economy and stronger interconnectedness with a global financial market, the risks of a future crisis are increasing. As to avoid a systemic event originating in China, and the necessity for a massive bailout that will come with it, the study suggests using the additional capital flows generated by a market liberalisation not to engage in immediate expansion but instead to improve the financial stability first. The ultimate goal should be to align the incentives within the system in a way that risk is adequately priced in. According to authors' opinion, this can be achieved by a combination of book based prudential regulation and market enforced discipline for which both SRISK can serve as a reference. These measures can in no way be considered static; instead, they could be seen as constantly updating book value measures that move in tandem with financial innovation and continuous efforts to increase information availability and transparency for market participants. Similarly, the assumptions of each individual measure should be tested regularly. Anticipating a move toward ever more complicated measures, reduced-form applications, such as the one of SRISK employed in this study should be made available for individual researchers and investors. The more independent pricing opinions the market will receive, the less likely it will be that risks and rewards are inadequately priced.

Indeed, investors and regulators alike my benefit from the information the model provides. Investors would have a reliable 
model for systemic risk to inform their pricing decision. Theory and historical evidence suggest that this will contribute to the financial stability of the whole system. Regulators, similarly, can benefit from the insights of a model, which offers information from two perspectives, book and market-based, and updates in short intervals. Furthermore, the way the model is represented in this study gives an easy, comparable ratio that can guide regulatory decisions. It is often necessary to adapt regulatory frameworks to the behaviour or size of individual institutions, the separation of banks into SIFIs in one example for that. The SRISK model accounts for this difference in risk taking behaviour. It is inherently beneficial to the whole system when low risk-taking firms are rewarded with lighter regulation.

\section{Implications of the study}

Since the 2008 financial crisis, the historical trend for systemic risk exposure of Chinese SIFIs has been rising. For most companies, this could have harmful implications. As non-financial companies in the wider economy begin to show cash flow problems, they rely on bank lending to keep their payment schedules. Even though the economic situation is stabilising, bad debt remains a centrepiece problem. These two factors are heightening the risk for a widespread capital shortfall in the system. The relative seclusion of the Chinese market that safeguarded it from much of the impact of the global financial crisis is decreasing, and already during the subsequent Euro crisis, one could observe stronger co-movement. The trend toward higher systemic risk is, however, is not captured by most traditional risk measures, and thus remains translucent for many investors. This could potentially give rise to mispricing similar the ones that triggered the previous crises.

Exacerbated and partly explained is this trend by the fact that the same regulation that intended to increase financial stability globally is not particularly sensitive to systemic risk. It thus fails to incentivise firms to reduce their risk exposure. These stray incentives are strongly observable in the SIFIs subject of this study. The reason for that is that their main shareholders remain government institutions, which inadvertently reduces the real cost of failure. 
Expecting a bailout, the firms instead use their systemic importance to the whole system as free insurance and lever up.

Stronger co-movement of international and mainland markets may also imply that a systemic event originated in the Chinese market could go global. Chinese financial institutions and more importantly the firms that rely on their credits to operate are, due to their trade exposure, increasingly interconnected with other markets. Already markets worry about the effects of a slowdown in the Chinese economy. Continuous efforts to liberalise Chinese markets and make them more accessible may come with additional capital liquidity, but if not done right at a cost to global financial stability.

\section{Limitations And Future Research}

The present study is also not free from limitations. It only focusses on global systemically important institutions, with the exception of two illustrative examples. This omission may influence the transferability of the findings. Taking data from the latest PBC Annual Report (中国人民银行 2015 年报) one finds that the four SIFIs analysed in this report have a total asset share of around 38\% of the overall banking market. This does not transgress the IMF standard stress test threshold of $90 \%$ of the whole sector. In effect, the scope of this study may only hint at systemic risk exposure in the more regulated, systemic institutions and omit liabilities looming in smaller more leveraged market participants. For further research, it is suggested to extend the approach both in scope and scale.

Effective market pricing might be inhibited in cases where investors under-price risk, assuming that the bank will be rescued by the governments. This is especially the case for SIFIs, and more significantly so for the Chinese SIFIs, as their majority shareholders remain state institutions. In these cases, regulation is especially important; consequences are that a market-based measure such as SRISK may be biased by the expectations of a rescue. 
The need for publicly available data reduces the scope of this measure to publicly listed companies. Private enterprises lie beyond that scope. This imposed a serious limitation to this paper's findings, as had to leave out China's big asset management companies and could only focus on its banks and insurance companies. Essentially, a considerable stake of the financial market is missing. While in much of the developed equity markets almost all firms in the financial industries are public, strategically important ones remain in private or state hands in countries with lesser developed markets. Interestingly, it is these countries that would most benefit from market-based risk valuations, as it can have advantages over bookbased appraisals when reporting and auditing are immature.

Using a hybrid model between balance sheet data and market data comes with various advantages, but also some drawbacks. For example, the very reliance on balance sheet data makes the model less responsive than purely market-based models. Should a crisis erupt, so is it likely that the crisis falls in between reporting periods. The model then uses old data as a basis of the analysis, muting its response and skewing the predicted shortfall and exposure, especially when more complex estimators are used as input. Still, as liabilities and number of shares are the only core balance sheet inputs, it remains unlikely that the two values abruptly change, especially in the former case, and similarly most changes in the latter would be outpriced by the market.

When applying the SRISK model, one can employ a different way of estimating beta. As previously discussed, many of the older models show weaknesses in empirical testing. Engle (2012a) suggested using the DCC beta instead. However, the present argues that for understanding some of the key implications of SRISK and systemic risk in general, a CAPM beta can be considered enough. For more accurate results, this study proposes to apply a beta estimation that fits the specific scope of the analysis. While a more comprehensive measure will increase estimation accuracy, it will come at a cost to simplicity. 
One notable point that may be raised is the difference between the Chinese and Hong Kong market. Indeed, Chinese markets are somewhat unique when it comes to day to day business rules and norm. One example is that trading in mainland markets is constrained to a price floor based on previous day's close. This poses a direct price limit to losses, inadvertently influencing the risk behaviour of investors (Wan, Cheng \& Yang, 2014).

Another problem endemic to all stress tests and models looking at tail events such as crises is the relative lack thereof. While they tend to leave a dominant impact on society's and investors' minds, they sum to only a few data points. Adding to that difficulty is the oftendifferent cause of crises. This makes it hard to confidently scrutinise previous crises without sample related distortions. This study did not find a solution to this problem, however, avoided the difficulties of determining probabilities of default by employing a reverse stress test model. Its assumptions are, however, still constraint by the lack of comparable data. Another factor that has to be considered is the implicit government guarantees institutions and investors receive. For example, trading - as was seen during the 15-16 flash crashhalts should losses be too severe. Similarly, the banks itself are considered to be guaranteed by the government and thus have a similar incentive structure than other too-big-to-fail banks. This may cause an underestimation of risk to substantiate in the market price.

Further research could aim into two directions. First the approach should be applied at a bigger scale and scope, including other markets. By that, the relationship between systemic risk and overall banking performance could be explored further. The trade-off between SRISK and performance was not verified, thus further empirical analysis of this relationship could be of interest as well. Secondly, using different components within the model, such as a more accurate beta estimator may enhance and verify the findings of this paper. Additionally, the shifting linear relationship between returns and SRISK could be explored further. 


\section{References}

Acharya, V. (2001). Theory of Systemic Risk and Design of Prudential Bank Regulation. Retrieved from http://papers.ssrn.com/sol3/papers.cfm?abstract_id=236401\&rec $=1 \&$ srcabs $=1611229 \&$ alg $=7 \&$ pos $=3$

Acharya, V. (2009). A theory of systemic risk and design of prudential bank regulation. Journal of financial stability, 5(3), 224-255.

Acharya, V. Cooley, T. Richardson, M. \& Walter, I. (2010), Regulating Wall Street: The Dodd-Frank Act and the New Architecture of Global Finance. USA: Wiley

Acharya, V. Engle, R. and Richardson, M, (2012). Capital Shortfall: A New Approach to Ranking and Regulating Systemic Risks. American Economic Review: Papers \& Proceedings 2012, 102(3): 59-64

Acharya, V. V., Pierret, D., \& Steffen, S. (2016). Lender of Last Resort versus Buyer of Last Resort-The Impact of the European Central Bank Actions on the Bank-Sovereign Nexus. ZEW-Centre for European Economic Research Discussion Paper, (16-019).

Adrian, T., \& Shin, H. S. (2010). Liquidity and leverage. Journal of financial intermediation, 19(3), 418-437.

Amihud, Y., Mendelson, H., \& Pedersen, L. H. (2006). Liquidity and asset prices. MPRA Paper No. 24768

Antonios A., Yilmaz G., and Krishna P. (2008). The Determinants of Capital Structure: Capital Market-Oriented versus Bank-Oriented Institutions. Journal of Financial and Quantitative Analysis, 43, pp 59-92. Retrieved from https://www.researchgate.net/profile/Antonios_Antoniou3/publi cation/

Bali, T. G., Engle, R. F., \& Tang, Y. (2015). Dynamic conditional beta is alive and well in the cross-section of daily stock returns. Retrieved from http://eaf.ku.edu.tr/sites/eaf.ku.edu.tr/files/erf_wp_1305.pdf 
Basurto, M. A. S., Jones, B., Lindner, P., \& Blankenheim, J. (2013). Securitization: Lessons Learned and the Road Ahead (No. 13255). International Monetary Fund.

Bekaert, G., \& Harvey, C. R. (1997). Emerging equity market volatility. Journal of Financial economics, 43(1), 29-77.

Benoit, S. (2013). Where is the system?. University of Orleans. Retrieved from http://afse2013.sciencesconf.org/conference/afse2013/pages/Ben oit_WhereIsTheSystem_2013.pdf

Bernanke, B. (1983). Non-Monetary Effects of the Financial Crisis in the Propagation of the Great Depression. The American Economic Review, Vol. 73, No. 3, pp. 257-276.

Bisias, D., Flood, M. D., Lo, A. W., \& Valavanis, S. (2012). A survey of systemic risk analytics. US Department of Treasury, Office of Financial Research. Retrieved from http://dspace.mit.edu/openaccess-disseminate/1721.1/87772

Black, F., Jensen, M. C., \& Scholes, M. (1972). Studies in the theory of capital markets. Retrieved from http://www.competitiontribunal.gov.au/_data/assets/pdf_file/00 03/28245/END.042.001.0012.pdf

Brownlees, C. T., \& Engle, R. (2010). Volatility, correlation and tails for systemic risk measurement. Retrieved from https://bfi.uchicago.edu/sites/default/files/research/SSRNid1611229.pdf

Brownlees, C. T., \& Engle, R. F. (2015). SRISK: A Conditional Capital Shortfall Measure of Systemic Risk. Retrieved from https://papers.ssrn.com/sol3/papers.cfm?abstract_id=1611229

Bullard, J., Neely, C. J., \& Wheelock, D. C. (2009). Systemic risk and the financial crisis: A primer. Federal Reserve Bank of St. Louis Review, September/October 2009, 91(5, Part 1), pp. 403-17. 
Calluzzo, P. \& Dong, N. (2015). Has the financial system become safer after the crisis? The changing nature of financial institution risk. Journal of Banking \& Finance, 53, 233-248.

Chrystal, K. A., \& Mizen, P. D. (2003). Goodhart's Law: its origins, meaning and implications for monetary policy. Central banking, monetary theory and practice: Essays in honour of Charles Goodhart, 1, 221-243.

De Bandt, O. and Hartmann, P. (2000). Systemic Risk: A Survey. ECB Working Paper No. 35. Retrieved from https://www.ecb.europa.eu/pub/pdf/scpwps/ecbwp035.pdf

Dell'Ariccia, G., Laeven, L., \& Suarez, G. (2014). Bank leverage and monetary policy's risk-taking channel: evidence from the United States. Retrieved from http//www8.gsb.columbia.edu/facultyresearch/sites/facultyresearch/files/finance/Finance\%20Seminar/Fall\%202014/DellAr iccia\% 20Laeven\%20Suarez\%20June \%2026\% 202014.pdf

Eijffinger, S. (2011). Defining and Measuring Systemic Risk. In Eijffinger, S., \& Masciandaro, D. (Eds.) (2011). Handbook of Central Banking, Financial Regulation and Supervision: After the Financial Crisis. Cheltenham, UK: Edward Elgar Publishing

Eisenberg, L., \& Noe, T. H. (2001). Systemic risk in financial systems. Management Science, 47(2), 236-249.

Engle, R. (2012a). Dynamic Conditional Beta. NYU Stern. Retrieved from http://archive.nyu.edu/bitstream/2451/31582/2/DYNAMIC\%20 CONDITIONAL\%20BETA.6.13-1.pdf

Engle, R., \& Kelly, B. (2012b). Dynamic equicorrelation. Journal of Business \& Economic Statistics, 30(2), 212-228.

Engle, R., Jondeau, E., \& Rockinger, M. (2015). Systemic risk in Europe. Review of Finance, 19(1), 145-190.

European Central Bank (ECB), 2010, "Financial networks and financial stability," Financial Stability Review, 2010, 155-160. 
Fama, E. F. (1998). Market efficiency, long-term returns, and behavioral finance. Journal of financial economics, 49(3), 283-306.

Fama, E. F., \& French, K. R. (1992). The cross-section of expected stock returns. The Journal of Finance, 47(2), 427-465.

Fama, E.F. and French, K.R. (2012). Capital Structure Choices. Critical Finance Review, 2012, 1: 59-101. Retrieved from http://cfr.ivowelch.info/readers/pub/cfr-002.pdf

Fan, X., Wang, D. \& Fang Y. (2011). Measuring and Supervising Financial Instituites' Marginal Contribution to Systemic Risk in China: A Research based on MES and Leverage. Nankai Economic Studies, (4).

Fiordelisi, F., Marques-Ibanez, D., \& Molyneux, P. (2011). Efficiency and risk in European banking. Journal of Banking \& Finance, 35(5), 1315-1326.

Friedman, M., \& Schwartz, A. J. (2008). A Monetary History of the United States, 1867-1960. Princeton: Princeton University Press.

Galati, G., \& Moessner, R. (2013). Macroprudential policy-a literature review. Journal of Economic Surveys, 27(5), 846-878. Retrieved from http://www.dnb.nl/binaries/267\% 20\%20Macroprudential_tcm46-243120.pdf

Gao Z.-Y. (2 (2010). Systemic Risk and Macro-prudential Regulation: Empirical Research on US Banks. The Theory and Practice of Finance and Economics (3).

Gao, G. H., Pan Y.-L., (2011). Banking systemic risk based on dynamic CoVaR estimation. Shanghai Jiaotong Daxue Xuebao/Journal of Shanghai Jiaotong University 45(12):1753-1759

Gibson, M. S. (1997). More evidence on the link between bank health and investment in Japan. Journal of the Japanese and international Economies, 11(3), 296-310. Retrieved from http://citeseerx.ist.psu.edu/viewdoc/download?doi=10.1.1.196.7 $059 \&$ rep $=$ rep $1 \&$ type $=$ pdf 
Giglio, S., Kelly, B., \& Pruitt, S. (2016). Systemic risk and the macroeconomy: An empirical evaluation. Journal of Financial Economics, 119(3), 457-471.

Gomez, P. Y., \& Korine, H. (2008). Entrepreneurs and democracy: A political theory of corporate governance. Cambridge University Press. Retrieved from http://www.langtoninfo.com/web_content/9780521169608_fron tmatter.pdf

Gorton, G. (2014). Some reflections on the recent financial crisis. NBER Working paper (w18397). Retrieved from http://www.nber.org/papers/w18397

Haldane, A. G., \& May, R. M. (2011). Systemic risk in banking ecosystems. Nature, 469(7330), 351-355.

Hansen, L. P. (2012). Challenges in identifying and measuring systemic risk. National Bureau of Economic Research (No. w18505). Retrieved from http://www.cemfi.edu.es/ftp/wp/1305.pdf

He, D., Zhang, Z., \& Wang, H. (2009). Hong Kong's Financial Market Interactions with the US and Mainland China in Crisis and Tranquil Times. Hong Kong Monetary Authority Working Paper (No. 0910).

Hilbers, M. P. L. C., Jones, M. M. T., \& Slack, M. G. L. (2004). Stress Testing Financial Systems: What to Do When the Governor Calls (No. 4-127). International Monetary Fund.

Holmstrom, B., \& Tirole, J. (1997). Financial intermediation, loanable funds, and the real sector. The Quarterly Journal of Economics, 663-691.

Hsu, S., Li, J., \& Xue, Y. (2014). Shadow banking and systemic risk in China. Political Economy Research Institute Working Paper, $349 . \quad$ Retrieved from https://pdfs. semanticscholar.org/4c19/5b3f294859b0cd2f64f3ca 732853a9d69e41.pdf 
Hughes, J. P., \& Mester, L. J. (2008). Efficiency in banking: theory, practice, and evidence. Federal Reserve Bank of Philadelphia Working Paper. Retrieved from http://citeseerx.ist.psu.edu/viewdoc/download?doi=10.1.1.416.8 $492 \&$ rep $=$ rep $1 \&$ type $=$ pdf

International Monetary Fund (IMF). (2014). A Guide to IMF Sress Testing Methods and Models. Ong, L. L. (Ed.). USA: IMF

Kasumovic, M. (2015). Chasing the Tail of Financial Stability? Solutions to the Last Crisis Are the Seeds for the Next One. In Thomakos, D. D., Monokroussos, P., Nikolopoulos, K. I. (2015) A Financial Crisis Manual (pp 81-101). UK: Palgrave Macmillan.

Laeven, L. \& Levine, R. (2009). Bank governance, regulation and risk taking. Journal of Financial Economics, vol. 93(2), pages 259275

Li, L., Willett, T. D., \& Zhang, N. (2012). The effects of the global financial crisis on China's financial market and macroeconomy. Economics Research International, 2012.

Ma, J.-L,. Fan, X.-Y. \& Cao, Y.-T. (2007). Estimating Bilateral Exposures in the China Interbank Market:Is There a Systemic Contagion? Economic Research Journal (1).

Marois, T. (2012). Finance, finance capital and financialization. In Fine, B., Saad-Filho, A. \& Boffo, M. (Ed.). (2012). The Elgar Companion to Marxist Economics. UK: Edward Elgar Publishing.

Merton, R. C. (1973). An intertemporal capital asset pricing model. Econometrica: Journal of the Econometric Society, 867-887.

Miller, M. H., \& Scholes, M. (1972). Rates of return in relation to risk: A reexamination of some recent findings. Studies in the theory of capital markets, 23.

Obstfeld, M. (2013). Finance at center stage: Some lessons of the euro crisis. European Commission Economic Papers 493. Retrieved from 
http://ec.europa.eu/economy_finance/publications/economic_pa per/2013/pdf/ecp493_en.pdf

Orhangazi, Ö. (2008). Financialisation and capital accumulation in the nonfinancial corporate sector: A theoretical and empirical investigation on the US economy: 1973-2003. Cambridge. Journal of Economics, 32 (6): 863

Rochet, J. and Tirole, J. (1996). Interbank Lending and Systemic Risk. Journal of Money, Credit and Banking. 28, issue 4, p. 733-62, Retrieved

from http://EconPapers.repec.org/RePEc:mcb:jmoncb:v:28:y:1996:i:4 :p:733-62.

Roll, R. (1977). A critique of the asset pricing theory's tests Part I: On past and potential testability of the theory. Journal of financial economics, 4(2), 129-176.

Rosenberg, B., Reid, K., \& Lanstein, R. (1985). Persuasive evidence of market inefficiency. The Journal of Portfolio Management, 11(3), 9-16.

Sharpe, W. F. (1964). Capital asset prices: A theory of market equilibrium under conditions of risk. The Journal of Finance, 19(3), 425-442.

Shin, H. S. (2009). Securitisation and financial stability. The Economic Journal, 119(536), 309-332.

Slovik, P. (2012). Systemically Important Banks and Capital Regulation Challenges. OECD Economics Department Working Papers, No. 916.

Slovin, M. B., Sushka, M. E., \& Polonchek, J. A. (1993). The value of bank durability: Borrowers as bank stakeholders. The Journal of Finance, 48(1), 247-266.

Smaga, P. (2014). The concept of systemic risk. Systemic Risk Centre Special Paper, (5). Retrieved from http://eprints.lse.ac.uk/61214/1/sp-5.pdf 
Su, Q., Chong, T. T. L., \& Yan, I. K. M. (2007). On the convergence of the Chinese and Hong Kong stock markets: a cointegration analysis of the A and H shares. Applied Financial Economics, 17(16), 1349-1357.

Sun, L. \& Chang, T-P. (2011). A comprehensive analysis of the effects of risk measures on bank efficiency: Evidence from emerging Asian countries. Journal of Banking and Finance. 35 (2011) 1727-1735.

Thakor, A. V. (1996). The design of financial systems: An overview. Journal of Banking \& Finance, 20(5), 917-948. Retrieved from http://apps.olin.wustl.edu/workingpapers/pdf/2006-06-040.pdf

Treynor, J. L. (1961). Market value, time, and risk. Time, and Risk (August 8, 1961). Retrieved from https://papers.ssrn.com/sol3/papers.cfm?abstract_id=2600356

Virkar, S. (2016). Predicting Global Financial Meltdown and Systemic Banking Failure: An Assessment of Early Warning Systems (EWSs) and Their Current Relevance. In Q. Munir (Ed.), Handbook of Research on Financial and Banking Crisis Prediction through Early Warning Systems (pp. 46-79). Hershey, PA: IGI Retrieved from:10.4018/978-1-4666-9484-2.ch003

Wan, D., Cheng, K., \& Yang, X. (2014). The reverse volatility asymmetry in Chinese financial market. Applied financial economics, 24(24), $1555-1575$.

Welch, I. (2011). Two Common Problems in Capital Structure Research: The Financial-Debt-To-Asset Ratio and Issuing Activity Versus Leverage Changes. International Review of Finance, 11(1), 1-17. 